\title{
Replacing alfalfa silage with tannin-containing birdsfoot trefoil silage in total mixed rations for lactating dairy cows ${ }^{1}$
}

\author{
G. A. Broderick, ${ }^{2,3}$ J. H. Grabber, R. E. Muck, ${ }^{4}$ and U. C. Hymes-Fecht \\ Agricultural Research Service, USDA, US Dairy Forage Research Center, Madison, WI 53706
}

\begin{abstract}
Two lactation trials were conducted comparing the feeding value of silages made from birdsfoot trefoil (BFT, Lotus corniculatus L.) that had been selected for low (BFTL), medium (BFTM), and high (BFTH) levels of condensed tannins (CT) to an alfalfa silage (AS) when fed as the principal forage in total mixed rations. Diets also included corn silage, high-moisture shelled corn, soybean meal, soy hulls, and supplemental fat. In trial 1, 32 lactating Holstein cows were blocked by days in milk, assigned to treatment sequences in 8 balanced $4 \times 4$ Latin squares, and fed $50 \%$ dietary dry matter from $\mathrm{AS}$ or 1 of $3 \mathrm{BFT}$ silages containing $0.6,1.2$, or $1.7 \%$ CT. Diets averaged 17.5 to $19.5 \%$ crude protein and $26 \%$ neutral detergent fiber on a dry matter basis. Data were collected over the last 2 wk of each 4 -wk period. Intakes were 1.3 to $2.8 \mathrm{~kg}$ of dry matter/d greater on BFT than on AS and cows gained $0.5 \mathrm{~kg}$ of body weight/d on BFT diets while losing $0.14 \mathrm{~kg}$ of body weight/d on the AS diet; this resulted in greater milk per dry matter intake (DMI) on AS. Linear effects indicated true protein yield and milk urea nitrogen declined with increasing CT concentration and quadratic effects indicated DMI, energy-corrected milk, and fat yield were increased at intermediate CT concentration. True protein yield and apparent N-efficiency were greater, and milk urea nitrogen lower, on all BFT diets than on AS. In trial 2, 50 lactating Holstein cows were fed a covariate AS diet for 2 wk and then blocked by parity and days in milk and randomly assigned to 1 of 5 diets that were fed continuously for 12 wk. Diets contained (dry matter basis) $48 \%$ AS, $16 \%$ AS plus $32 \%$ of 1 of
\end{abstract}

Received September 29, 2016.

Accepted January 10, 2017.

${ }^{1}$ Mention of any trademark or proprietary product in this paper does not constitute a guarantee or warranty of the product by the USDA or the Agricultural Research Service and does not imply its approval to the exclusion of other products that also may be suitable.

${ }^{2}$ Present address: Broderick Nutrition \& Research LLC, 221 Glen Hollow Road Madison, WI 53705.

${ }^{3}$ Corresponding author: gbroderi@wisc.edu

${ }^{4}$ Present address: 10871 Boyd Drive, Clarence, NY 14031.
3 BFT silages with $0.5,0.8$, or $1.5 \% \mathrm{CT}$, or $48 \%$ of an equal mixture of each BFT silage. Diets averaged 16.5\% crude protein and $30 \%$ neutral detergent fiber. Intake and milk yield tended to be lower on AS than BFT, but body weight gains averaged $0.6 \mathrm{~kg} / \mathrm{d}$ on all diets. Cows fed any of the BFT silages had reduced milk urea nitrogen and ruminal ammonia and reduced urinary $\mathrm{N}$ excretion. Feeding the BFT mixture reduced concentrations of milk true protein and milk urea nitrogen and depressed apparent nutrient digestibility. Among diets containing the individual BFT silages, linear reductions in DMI and yield of milk, fat, true protein, lactose, and SNF were observed with increasing CT concentration. By contrast, a previous trial with the same BFT populations showed that substituting BFTH silage containing $1.6 \% \mathrm{CT}$ for $\mathrm{AS}$ in rations containing $60 \%$ silage dry matter had no effect on intake, increased yield of milk, energy-corrected milk and milk components, elevated protein use-efficiency, but with a more modest reduction in milk urea nitrogen and urinary N excretion. Silage analyses suggested that the inconsistent responses among trials were related to growth environment or ensiling effects that altered tannin-protein interactions in BFT silage. Differences in diet formulation among trials may have also influenced responses. Results from the current and previous trials indicate further work is needed to identify optimum tannin levels in forages. Key words: birdsfoot trefoil silage, alfalfa silage, condensed tannins, milk yield

\section{INTRODUCTION}

Many legumes contain condensed tannins (CT) that undergo hydrophobic interactions and hydrogen bonding with proteins in conserved forages (MuellerHarvey, 2006; Patra and Saxena, 2011). This action of CT reduces protein breakdown and NPN formation during ensiling (Albrecht and Muck, 1991; Grabber and Coblentz, 2009) and during ruminal fermentation (Broderick and Albrecht, 1997; Coblentz and Grabber, 2013). Both processes increase RUP supply and, in some cases, intestinal absorption of essential AA in ruminants (Waghorn et al., 1987; Wang et al., 1996b). 
Several reports in the literature have shown that presence of CT in some legume forage species improved growth and milk production of ruminants (Wang et al., 1996a; Woodward et al., 1999, 2000; Min et al., 2003; Hymes-Fecht et al., 2013). Feeding of CT-containing forages to ruminants also reduced the excretion of urinary urea and emissions of ammonia from manure to the environment (Misselbrook et al., 2005). These findings have spurred efforts to bioengineer CT production in herbage of major forage crops such as alfalfa to improve the performance of ruminant livestock ( $\mathrm{Li}$ et al., 2016).

The chemical properties of CT and their interaction with forage proteins differ substantially according to the legume from which they originate (Lorenz et al., 2014). In his review, Waghorn (2008) provided evidence that the legume birdsfoot trefoil (BFT; Lotus corniculatus L.) produces a type of $\mathrm{CT}$ in its foliage that is particularly effective for improving ruminant performance. For example, when fed diets consisting of all fresh-cut forage, BFT improved milk production in dairy cows (Woodward et al., 1999, 2000) and ewes (Wang et al., 1996a) compared with BFT treated with polyethylene glycol to inactivate CT.

Miller and Ehlke (1996) divergently selected BFT to develop populations containing low, medium, and high concentrations of CT. We observed improved yields of milk and true protein when all 3 of these BFT forages were fed as silages to lactating cows versus alfalfa silage (AS) and red clover silage (Hymes-Fecht et al., 2013). Surprisingly, the CT containing BFT silages did not contain lower proportions of NPN than the AS control in that study. To confirm our earlier observations, we ensiled and fed silages from the same 3 BFT populations in 2 additional lactation trials. Our hypothesis was that the presence of $\mathrm{CT}$ in BFT would, relative to the AS control, improve protein utilization for milk production in lactating dairy cows. Moreover, we wished to identify the CT concentration that would optimize cow performance.

\section{MATERIALS AND METHODS}

\section{Legume Forages}

As described in Hymes-Fecht et al. (2013), populations of NC-83 BFT with low CT (BFTL), medium (BFTM), and high (BFTH) concentrations of CT (Miller and Ehlke, 1996) were planted on April 17, 2002 , at an average seeding rate of $10.3 \mathrm{~kg} / \mathrm{ha}$. The alfalfa varieties Forecast 1001 and Rebound 4.2 were planted April 11 and April 24, 2002, at average seeding rates of 14.6 and $16.8 \mathrm{~kg} / \mathrm{ha}$, respectively. All forages were planted on silt loam soils in adjacent fields of the US Dairy Forage Research Center farm at Prairie du Sac, Wisconsin, using a no-till planter with row spacing of $19 \mathrm{~cm}$. For the current studies, second-cutting BFT for trial 1 was mowed and conditioned with rollers on July 14, 2004, after $42 \mathrm{~d}$ of regrowth, wilted for $1 \mathrm{~d}$ to about 40\% DM, chopped with a New Holland FX 58 forage harvester (CNH Global, New Holland, PA) to a 2-cm theoretical length of cut, and immediately ensiled at the production fields into bag silos (Ag-Bag model G6000, Agbag Systems Inc., St. Nazianz, WI). Just before feeding, BFT silages were moved on October 26, 2004, from production fields and repacked into bag silos placed near the dairy barn. Trial 2 used BFT from 2 harvests, second-cutting BFT mowed on July 16, 2003, after $31 \mathrm{~d}$ of regrowth and first-cutting mowed on June 2 , 2004. Both harvests were wilted 1 to $2 \mathrm{~d}$ to about $40 \%$ DM and then chopped and ensiled as described above. Just before feeding, silages from both cuttings were moved from the field on around November 30, 2005, mixed by BFT population (to provide sufficient forage for trial 2), and repacked into silo bags placed near the dairy barn. Botanical separations of samples taken immediately before harvest indicated the DM of BFT silages was composed of $72 \%$ BFTL, $84 \%$ BFTM, and $77 \%$ BFTH in trial 1; dandelion followed by quackgrass were the primary weeds with BFTL, whereas weeds with BFTM and BFTH were composed of a roughly equal mix of dandelion, red clover, and white clover. The purity of all BFT silages used in trial 2 exceeded $85 \%$ of DM and dandelion was the most prevalent weed. The alfalfa control silages were a fourth cutting mowed on August 31, 2004, for trial 1 and a fourth cutting mowed on August 23, 2005, for trial 2. After mowing, alfalfa was wilted and chopped as described above for BFT and then ensiled in a bunker silo for trial 1 and an upright silo for trial 2 .

Before ensiling, subsamples of chopped BFT were quick-frozen in liquid nitrogen and subsequently freezedried, ground through a 1-mm screen of a cyclone mill (Udy Corp., Fort Collins, CO), and analyzed for total $\mathrm{CT}$ by a conventional butanol-HCl method (Grabber, 2008). Subsequent work with an improved acetonebutanol- $\mathrm{HCl}$ assay (Grabber et al., 2013) on an independent set of BFT samples (Grabber et al., 2015) suggested that the conventional butanol- $\mathrm{HCl}$ assay probably underestimated total CT content of BFT silages by about $17 \%$. Because results from the 2 methods are highly correlated (Grabber et al., 2015), and our desire to maintain consistency with our companion paper (Hymes-Fecht et al., 2013), CT concentrations reported here were derived from the conventional butanol- $\mathrm{HCl}$ assay. 
Table 1. Composition of legume forages (trial 1)

\begin{tabular}{|c|c|c|c|c|c|c|}
\hline \multirow[b]{2}{*}{ Item } & \multicolumn{4}{|c|}{ Forage $^{1}$} & \multirow[b]{2}{*}{ SEM } & \multirow[b]{2}{*}{$F>P$} \\
\hline & Alfalfa & BFTL & BFTM & BFTH & & \\
\hline \multicolumn{7}{|l|}{ Before ensiling } \\
\hline Condensed tannins, $\%$ of DM & - & $0.56^{\mathrm{c}}$ & $1.17^{\mathrm{b}}$ & $1.66^{\mathrm{a}}$ & 0.048 & $<0.01$ \\
\hline \multicolumn{7}{|l|}{ Silage composition } \\
\hline DM, $\%$ of as fed & $33.5^{\mathrm{c}}$ & $43.5^{\mathrm{a}}$ & $37.2^{\mathrm{b}}$ & $41.4^{\mathrm{a}}$ & 0.92 & $<0.01$ \\
\hline $\mathrm{CP}, \%$ of $\mathrm{DM}$ & $26.4^{\mathrm{a}}$ & $21.1^{\mathrm{b}}$ & $20.5^{\mathrm{b}}$ & $19.2^{\mathrm{c}}$ & 0.24 & $<0.01$ \\
\hline Ash, \% of DM & $12.9^{\mathrm{a}}$ & $9.8^{\mathrm{b}}$ & $10.1^{\mathrm{b}}$ & $10.1^{\mathrm{b}}$ & 0.22 & $<0.01$ \\
\hline $\mathrm{NDF}, \%$ of DM & $35.6^{\mathrm{b}}$ & $35.5^{\mathrm{b}}$ & $38.1^{\mathrm{a}}$ & $36.7^{\mathrm{b}}$ & 0.44 & 0.01 \\
\hline $\mathrm{ADF}, \%$ of $\mathrm{DM}$ & $26.9^{\mathrm{c}}$ & $28.1^{\mathrm{b}}$ & $30.2^{\mathrm{a}}$ & $29.1^{\mathrm{ab}}$ & 0.37 & $<0.01$ \\
\hline NDIN, $\%$ of total $\mathrm{N}$ & $15.0^{\mathrm{c}}$ & $17.2^{\mathrm{bc}}$ & $20.0^{\mathrm{ab}}$ & $20.2^{\mathrm{a}}$ & 0.96 & 0.01 \\
\hline ADIN, $\%$ of total $N$ & 4.5 & 5.3 & 5.7 & 5.1 & 0.45 & 0.33 \\
\hline Fraction $\mathrm{B} 3,^{2} \%$ of total $\mathrm{N}$ & $10.5^{\mathrm{b}}$ & $12.0^{\mathrm{ab}}$ & $14.2^{\mathrm{a}}$ & $15.1^{\mathrm{a}}$ & 1.09 & 0.05 \\
\hline \multicolumn{7}{|l|}{ Silage metabolites, $\%$ of DM } \\
\hline Lactate & $4.46^{\mathrm{b}}$ & $5.81^{\mathrm{a}}$ & $5.67^{\mathrm{a}}$ & $5.51^{\mathrm{a}}$ & 0.289 & 0.03 \\
\hline Acetate & $5.23^{\mathrm{a}}$ & $0.55^{\mathrm{b}}$ & $0.58^{\mathrm{b}}$ & $0.68^{\mathrm{b}}$ & 0.155 & $<0.01$ \\
\hline Succinate & $0.64^{\mathrm{a}}$ & $0.13^{\mathrm{b}}$ & $0.11^{\mathrm{b}}$ & $0.13^{\mathrm{b}}$ & 0.019 & $<0.01$ \\
\hline 2,3-Butanediol & $0.74^{\mathrm{a}}$ & $0.60^{\mathrm{b}}$ & $0.60^{\mathrm{b}}$ & $0.60^{\mathrm{b}}$ & 0.016 & $<0.01$ \\
\hline Ethanol & 0.03 & 0.03 & 0.03 & 0.04 & 0.014 & 0.88 \\
\hline Butyrate & $0.37^{\mathrm{a}}$ & $0^{\mathrm{b}}$ & $0^{\mathrm{b}}$ & $0^{\mathrm{b}}$ & 0.016 & $<0.01$ \\
\hline Formate & 0.02 & 0.02 & 0.05 & 0.03 & 0.014 & 0.53 \\
\hline Propionate & 0 & 0.02 & 0.01 & 0.03 & 0.011 & 0.51 \\
\hline 1,2-Propanediol & $0.04^{\mathrm{a}}$ & $0^{\mathrm{b}}$ & $0^{\mathrm{b}}$ & $0^{\mathrm{b}}$ & 0.005 & $<0.01$ \\
\hline
\end{tabular}

\section{Trial 1}

Thirty-two multiparous Holstein cows with mean (SD) parity $2.8(0.87), 128$ (66.9) DIM, 49 (6.3) $\mathrm{kg}$ of milk/d, and $659(59.4) \mathrm{kg}$ of BW at the start of the trial were used in this study. All cows were in good health and were housed in tie-stalls and had free access to water throughout the trial. The Animal Care and Use Committee for the College of Agriculture and Life Sciences of the University of Wisconsin-Madison approved all animal procedures. Cows were blocked by DIM into eight $4 \times 4$ Latin squares and randomly assigned to balanced dietary treatment sequences within squares. Dietary treatments were fed during four 4-wk periods (total of $16 \mathrm{wk}$ ). Each period allowed $2 \mathrm{wk}$ for adaptation and 2 wk for collection of production data and samples.

Diets were fed as TMR and contained about $50 \%$ of $\mathrm{DM}$ as legume forage from AS or 1 of the 3 BFT silages plus $50 \%$ of DM from corn silage, high-moisture shelled corn, solvent soybean meal plus minerals and vitamins. Corn silage fed in this trial was a brown midrib variety (F657, Cargill Hybrid Seeds, Minneapolis, MN) harvested at about $50 \%$ milk-line. The corn silage was chopped to a theoretical length of $1.9 \mathrm{~cm}$ with field processing of grain by kernel processor (roller clearance of 1 to $3 \mathrm{~mm}$ ) and then ensiled in a bunker silo. Composition of the legume silages fed in this trial is in
Table 1; composition of the corn silage, high-moisture shelled corn and soybean meal fed in this trial is in Table 2. Diets were formulated to contain $17 \% \mathrm{CP}$ and $28 \%$ NDF. Formulation of the AS diet was based on an initial determination of $21 \% \mathrm{CP}$; however, AS averaged $26 \% \mathrm{CP}$ over the course of the trial, and thus, the AS diet averaged about 2 percentage units higher in CP than the BFT diets. Cows were fed experimental diets once daily at $1000 \mathrm{~h}$ and orts were collected at $0900 \mathrm{~h}$. Feeding rate was adjusted daily to yield an orts equivalent of about 5 to $10 \%$ of intake.

Daily samples of approximately $0.5 \mathrm{~kg}$ of the legume silages, corn silage, high-moisture shelled corn, each TMR and mixed orts from each diet were collected and stored at $-20^{\circ} \mathrm{C}$ to obtain weekly composites that were used to determine the composition of the diets actually consumed during the trial. Soybean meal was sampled once each week. Weekly composites of the legume silages were dried at $55^{\circ} \mathrm{C}(48 \mathrm{~h})$, ground through a 1-mm screen (Wiley mill; Arthur H. Thomas, Philadelphia, PA), and retained for chemical analysis. Weekly composites of the corn silage, high-moisture shelled corn, TMR, orts, and soybean meal were dried at $60^{\circ} \mathrm{C}(48$ h). Dried TMR, corn silage, high-moisture corn, and soybean meal were ground through a 1-mm screen (Wiley mill) and retained for chemical analysis. Proportions of each ration ingredient on an as-fed basis were adjusted weekly based on these DM determinations. 
Table 2. Composition of other major dietary ingredients fed in trials 1 and 2

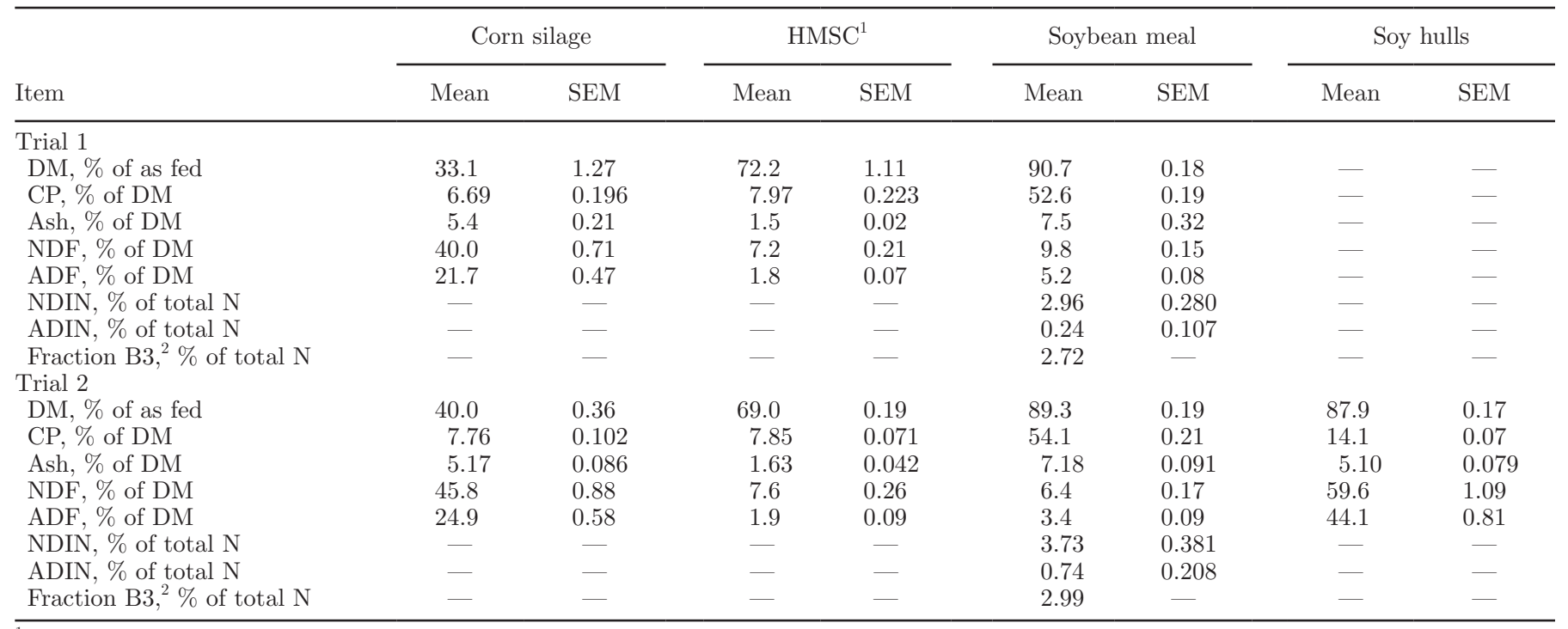

${ }^{1} \mathrm{HMSC}=$ high-moisture shelled corn.

${ }^{2}$ Fraction B3 $=$ NDIN - ADIN.

Intake of DM was computed based on the $60^{\circ} \mathrm{C} \mathrm{DM}$ values for TMR and orts. Dried weekly composites of each dietary ingredient were analyzed for $\mathrm{DM}$ at $105^{\circ} \mathrm{C}$, for ash and OM (AOAC, 1980), and for total $\mathrm{N}$ using a combustion assay (Leco FP-2000 N Analyzer, Leco Instruments Inc., St. Joseph, MI). Samples were analyzed sequentially for NDF and ADF including heat stable $\alpha$-amylase and $\mathrm{Na}_{2} \mathrm{SO}_{3}$ added during NDF extraction (Van Soest et al., 1991; Hintz et al., 1996). Combustion $\mathrm{N}$ analysis (Leco FP-2000 N Analyzer) of ADF residue was used to determine ADIN in legume silages and soybean meal. Dried legume silage composites and soybean meal were also analyzed for NDIN without use of $\mathrm{Na}_{2} \mathrm{SO}_{3}$ (Van Soest et al., 1991). The TMR composites were also analyzed for indigestible ADF (ADF remaining after $288 \mathrm{~h}$ of in situ incubation) by the method of Huhtanen et al. (1994). Period composites of the legume silages were extracted with distilled water as described by Muck (1987) and analyzed for succinate, lactate, formate, acetate, propionate, butyrate, 1,2-propanediol, ethanol, and 2,3-butanediol using HPLC methodology (Muck and Dickerson, 1988). Proportions of each ingredient and the chemical compositions (determined from proportions of DM from each ingredient and weekly analysis of ingredient composites) of the 4 diets fed during trial 1 are in Table 3 .

Cows were injected with rBST (500 mg of Prosaic; Monsanto, St. Louis, MO) every 14 d over the course of the trial. Cows were milked daily at 0500 and $1700 \mathrm{~h}$ and milk weights were recorded at every milking. Milk yields from wk 3 and 4 were used to compute a single mean daily milk yield for each cow in each period. Milk samples were collected from each cow at an a.m. and p.m. milking midway through wk 3 and 4, preserved with 2-bromo-2-nitropropane-1,3-diol, stored at $4^{\circ} \mathrm{C}$, and sent to AgSource Inc. (Verona, WI) for analysis of fat, true protein, lactose, SNF, and MUN by infrared method no. 972.16 (AOAC, 1990) using a Foss FT6000 instrument (Foss North America, Eden Prairie, MN). A single period mean yield was computed for fat, true protein, lactose, SNF, and MUN concentrations based on the weighted means from p.m. and a.m. milk yields on both test days. Yields of ECM also were computed as described by Krause and Combs (2003). Efficiency of feed conversion was calculated for each cow in each period by dividing mean yield of milk and ECM by mean DMI over the last 2 wk of each period. Efficiency of feed $\mathrm{N}$ utilization was computed for each cow in each period by dividing mean milk $\mathrm{N}$ output (milk true protein yield/6.38) by mean $\mathrm{N}$ intake. Cows were weighed on 3 consecutive days at the start of the trial and at the end of each period to compute BW change.

Spot urine and fecal samples also were collected at the end of wk 4 of each period at 0600 and $1800 \mathrm{~h}$. Urine was immediately diluted by mixing $15 \mathrm{~mL}$ of each urine sample with $60 \mathrm{~mL}$ of $0.072 \mathrm{~N} \mathrm{H}_{2} \mathrm{SO}_{4}$ and stored at $-20^{\circ} \mathrm{C}$ until analysis. Fecal samples were dried for $72 \mathrm{~h}$ at $60^{\circ} \mathrm{C}$, ground through a 1-mm screen (Wiley mill), and composited on an equal DM basis to obtain 1 fecal sample per cow per period. All fecal samples were analyzed for DM, OM, NDF, ADF, total N, and indigestible ADF using the assays described above. Indigestible ADF was used as an internal marker to estimate apparent nutrient digestibility and fecal output 
(Cochran et al., 1986). Urine samples were thawed and analyzed for total $\mathrm{N}$ by elemental analysis (Mitsubishi TN-05 Nitrogen Analyzer; Mitsubishi Chemical Corp., Tokyo, Japan) and for creatinine (Valadares et al., 1999). Daily urine volume and excretion of total N were estimated from mean urinary concentrations in each period assuming a creatinine excretion rate of $29 \mathrm{mg} /$ $\mathrm{kg}$ of BW (Valadares et al., 1999).

\section{Trial 2}

Fifteen primiparous and 35 multiparous Holstein cows, including 10 multiparous cows fitted with 10$\mathrm{cm}$ permanent ruminal cannulas (Bar Diamond Inc., Parma, ID), were used in this study. At the start of the trial, means (SD) for the 15 primiparous cows were 121 (40.0) DIM, 40 (3.3) kg of milk/d, and 554 (52.1) $\mathrm{kg}$ of $\mathrm{BW}$, and for the 35 multiparous cows were parity 2.8 (0.98), 137 (97.9) DIM, 46 (7.7) $\mathrm{kg}$ of milk/d, and 639 (70.0) $\mathrm{kg}$ of BW. All cows were in good health and were housed in tie-stalls with free access to water throughout the trial. The Animal Care and Use Committee for the College of Agriculture and Life Sciences of the
University of Wisconsin-Madison approved all animal procedures. Cows were fed a covariate diet for $2 \mathrm{wk}$ and then blocked into 10 blocks based on parity, DIM, and cannulation status (2 blocks of cannulated cows) and randomly assigned to 1 of 5 dietary treatments within blocks. These dietary treatments were fed continuously for a total of $12 \mathrm{wk}$ so that results would be more applicable to on-farm feeding practices. Diets were fed as TMR and contained (DM basis) $48 \%$ AS (covariate and AS control diet), $16 \%$ AS plus $32 \%$ of 1 of the 3 BFT silages with varying levels of $\mathrm{CT}$, or $48 \%$ of a mixture of equal DM from all 3 BFT silages. Feeding a mixture of BFT with AS was done to conserve the limited supply of BFT silages for the 12-wk trial. Moreover, BFT silage might be fed to supplement AS under some situations. The balance of the diet was corn silage, high-moisture shelled corn, soy hulls, solvent soybean meal, supplemental fat, plus minerals and vitamins. Corn silage fed in this trial was a brown midrib variety (F657, Cargill Hybrid Seeds, Minneapolis, MN) harvested at about $50 \%$ milk-line. The corn was chopped to a theoretical length of $1.9 \mathrm{~cm}$ with field processing of grain by kernel processor (roller clearance of 1 to $3 \mathrm{~mm}$ ) and

Table 3. Diet composition (trial 1)

\begin{tabular}{|c|c|c|c|c|}
\hline \multirow[b]{2}{*}{ Item } & \multicolumn{4}{|c|}{ Legume silage source $^{1}$} \\
\hline & Alfalfa & BFTL & BFTM & BFTH \\
\hline \multicolumn{5}{|l|}{ Ingredient, $\%$ of DM } \\
\hline Alfalfa & 51.2 & 0.0 & 0.0 & 0.0 \\
\hline Low tannin BFT & 0.0 & 51.1 & 0.0 & 0.0 \\
\hline Normal tannin BFT & 0.0 & 0.0 & 51.8 & 0.0 \\
\hline High tannin BFT & 0.0 & 0.0 & 0.0 & 51.1 \\
\hline Corn silage & 10.4 & 10.4 & 10.4 & 10.3 \\
\hline High-moisture shelled corn & 32.6 & 31.0 & 29.7 & 29.0 \\
\hline Soybean meal & 5.1 & 6.9 & 7.3 & 8.9 \\
\hline Sodium bicarbonate & 0.31 & 0.31 & 0.31 & 0.31 \\
\hline Sodium chloride & 0.19 & 0.19 & 0.19 & 0.19 \\
\hline Dicalcium phosphate & 0.10 & 0.10 & 0.10 & 0.10 \\
\hline Vitamins-trace minerals $^{2}$ & 0.12 & 0.12 & 0.12 & 0.12 \\
\hline \multicolumn{5}{|l|}{ Composition } \\
\hline CT concentration, ${ }^{3} \%$ of DM & - & 0.29 & 0.61 & 0.85 \\
\hline $\mathrm{CP}, \%$ of DM & 19.5 & 17.6 & 17.6 & 17.5 \\
\hline Ash, $\%$ of DM & 7.7 & 6.0 & 6.2 & 6.1 \\
\hline Starch, ${ }^{4} \%$ of DM & 24.3 & 23.3 & 22.6 & 22.3 \\
\hline $\mathrm{NDF}, \%$ of DM & 25.2 & 25.2 & 26.8 & 25.8 \\
\hline $\mathrm{ADF}, \%$ of $\mathrm{DM}$ & 16.9 & 17.5 & 18.9 & 18.1 \\
\hline NDIN, \% of total N & 12.9 & 13.5 & 15.0 & 14.3 \\
\hline ADIN, $\%$ of total $\mathrm{N}$ & 3.1 & 3.2 & 3.5 & 2.9 \\
\hline Fraction $\mathrm{B} 3,{ }^{5} \%$ of total $\mathrm{N}$ & 9.8 & 10.2 & 11.5 & 11.4 \\
\hline Ether extract, ${ }^{4} \%$ of DM & 3.1 & 2.9 & 2.9 & 2.8 \\
\hline $\mathrm{NFC},{ }^{4} \%$ of $\mathrm{DM}$ & 47.1 & 50.7 & 49.2 & 50.2 \\
\hline \multicolumn{5}{|c|}{$\begin{array}{l}{ }^{1} \mathrm{BFTL}=\text { low tannin birdsfoot trefoil }(\mathrm{BFT}) ; \mathrm{BFTM}=\text { medium tannin birdsfoot trefoil; } \mathrm{BFTH}=\text { high tannin } \\
\text { birdsfoot trefoil. }\end{array}$} \\
\hline \multicolumn{5}{|c|}{$\begin{array}{l}{ }^{2} \text { Provided (per kilogram of DM): } 56 \mathrm{mg} \text { of } \mathrm{Zn}, 46 \mathrm{mg} \text { of } \mathrm{Mn}, 22 \mathrm{mg} \text { of Fe, } 12 \mathrm{mg} \text { of } \mathrm{Cu}, 0.9 \mathrm{mg} \text { of I, } 0.4 \mathrm{mg} \text { of } \\
\mathrm{Co}, 0.3 \mathrm{mg} \text { of Se, } 6,440 \mathrm{IU} \text { of vitamin A, } 2,000 \mathrm{IU} \text { of vitamin } \mathrm{D}, 16 \mathrm{IU} \text { of vitamin E, and } 12 \mathrm{mg} \text { of monensin. } \\
{ }^{3} \text { Condensed tannin }(\mathrm{CT}) \text { concentration of diets computed from CT content of ensiled forages (Table } 1 \text { ). } \\
{ }^{4} \text { Computed according to the NRC (2001) model. }\end{array}$} \\
\hline
\end{tabular}


Table 4. Composition of legume forages (trial 2)

\begin{tabular}{|c|c|c|c|c|c|c|}
\hline \multirow[b]{2}{*}{ Item } & \multicolumn{4}{|c|}{ Forage $^{1}$} & \multirow[b]{2}{*}{ SEM } & \multirow[b]{2}{*}{$F>P$} \\
\hline & Alfalfa & BFTL & BFTM & BFTH & & \\
\hline \multicolumn{7}{|l|}{ Before ensiling } \\
\hline Condensed tannins, $\%$ of DM & - & $0.51^{\mathrm{c}}$ & $0.84^{\mathrm{b}}$ & $1.48^{\mathrm{a}}$ & 0.047 & $<0.01$ \\
\hline \multicolumn{7}{|l|}{ Silage composition } \\
\hline $\mathrm{DM}, \%$ of as fed & $49.1^{\mathrm{a}}$ & $39.6^{\mathrm{c}}$ & $43.6^{\mathrm{b}}$ & $35.7^{\mathrm{d}}$ & 0.96 & $<0.01$ \\
\hline $\mathrm{CP}, \%$ of DM & $23.2^{\mathrm{ab}}$ & $22.9^{\mathrm{b}}$ & $22.8^{\mathrm{b}}$ & $23.9^{\mathrm{a}}$ & 0.23 & 0.01 \\
\hline Ash, $\%$ of DM & 9.9 & 9.7 & 9.9 & 9.7 & 0.15 & 0.69 \\
\hline $\mathrm{NDF}, \%$ of DM & $35.7^{\mathrm{b}}$ & $34.4^{\mathrm{b}}$ & $34.8^{\mathrm{b}}$ & $37.5^{\mathrm{a}}$ & 0.50 & $<0.01$ \\
\hline $\mathrm{ADF}, \%$ of $\mathrm{DM}$ & $26.2^{\mathrm{b}}$ & $27.2^{\mathrm{b}}$ & $27.3^{\mathrm{b}}$ & $29.5^{\mathrm{a}}$ & 0.43 & $<0.01$ \\
\hline Ammonia-N, $\%$ of total $\mathrm{N}$ & 2.57 & 2.66 & 2.71 & 3.06 & 0.279 & 0.63 \\
\hline Free $\mathrm{AA}-\mathrm{N},{ }^{2} \%$ of total $\mathrm{N}$ & 30.0 & 30.5 & 22.2 & 23.3 & 2.69 & 0.07 \\
\hline Total soluble N, \% of total $\mathrm{N}$ & $53.6^{\mathrm{ab}}$ & $54.5^{\mathrm{a}}$ & $49.9^{\mathrm{bc}}$ & $45.8^{\mathrm{c}}$ & 1.49 & $<0.01$ \\
\hline NPN, \% of total N & $43.5^{\mathrm{ab}}$ & $45.2^{\mathrm{a}}$ & $41.3^{\mathrm{b}}$ & $37.0^{\mathrm{c}}$ & $\begin{array}{l}1.49 \\
1.40\end{array}$ & $<0.01$ \\
\hline Soluble protein-N, $\%$ of total $\mathrm{N}$ & 10.1 & 9.3 & 8.6 & 8.8 & 0.47 & 0.13 \\
\hline NDIN, \% of total $\mathrm{N}$ & $15.0^{\mathrm{c}}$ & $14.1^{\mathrm{c}}$ & $17.2^{\mathrm{b}}$ & $23.6^{\mathrm{a}}$ & 0.47 & $<0.01$ \\
\hline ADIN, $\%$ of total $\mathrm{N}$ & $4.9^{\mathrm{c}}$ & $4.9^{\mathrm{c}}$ & $5.3^{\mathrm{b}}$ & $5.8^{\mathrm{a}}$ & 0.13 & $<0.01$ \\
\hline Fraction $\mathrm{B} 3,^{3} \%$ of total $\mathrm{N}$ & $10.1^{\mathrm{c}}$ & $9.2^{\mathrm{c}}$ & $11.9^{\mathrm{b}}$ & $17.8^{\mathrm{a}}$ & 0.45 & $<0.01$ \\
\hline $\mathrm{pH}$ & $4.54^{\mathrm{a}}$ & $4.25^{\mathrm{b}}$ & $4.33^{\mathrm{b}}$ & $4.45^{\mathrm{a}}$ & 0.033 & $<0.01$ \\
\hline \multicolumn{7}{|l|}{ Silage metabolites, $\%$ of DM } \\
\hline Lactate & $5.78^{\mathrm{a}}$ & $6.98^{\mathrm{b}}$ & $5.75^{\mathrm{a}}$ & $7.13^{\mathrm{b}}$ & 0.357 & 0.01 \\
\hline Acetate & $0.96^{\mathrm{a}}$ & $0.61^{\mathrm{bc}}$ & $0.51^{\mathrm{c}}$ & $0.79^{\mathrm{ab}}$ & 0.080 & $<0.01$ \\
\hline Succinate & $0.51^{\mathrm{a}}$ & $0.18^{\mathrm{b}}$ & $0.16^{\mathrm{b}}$ & $0.22^{\mathrm{b}}$ & 0.035 & $<0.01$ \\
\hline 2,3-Butanediol & $0.60^{\mathrm{b}}$ & $0.83^{\mathrm{a}}$ & $0.66^{\mathrm{b}}$ & $0.89^{\mathrm{a}}$ & 0.029 & $<0.01$ \\
\hline Ethanol & 0.05 & 0.04 & 0.04 & 0.02 & 0.007 & 0.06 \\
\hline Butyrate & 0.02 & 0.01 & 0.02 & 0.03 & 0.012 & 0.72 \\
\hline Formate & 0.01 & 0.01 & 0.03 & 0.01 & 0.009 & 0.13 \\
\hline Propionate & 0.03 & 0.02 & 0 & 0.01 & 0.014 & 0.54 \\
\hline 1,2-Propanediol & $0.09^{\mathrm{a}}$ & $0^{\mathrm{b}}$ & $0^{\mathrm{b}}$ & $0^{\mathrm{b}}$ & 0.016 & $<0.01$ \\
\hline
\end{tabular}

a-d Means with different superscripts differ $(P<0.05)$.

${ }^{1} \mathrm{BFTL}=$ low tannin birdsfoot trefoil; BFTM $=$ medium tannin birdsfoot trefoil; BFTH $=$ high tannin birdsfoot trefoil.

${ }^{2}$ Computed assuming $40.3 \mathrm{mmol}$ of total free AA/mg of $\mathrm{N}$ in legume silages (Broderick, 1987).

${ }^{3}$ Fraction B3 $=$ NDIN - ADIN

then ensiled in an upright silo. Diets were formulated to contain $16.5 \% \mathrm{CP}$ and $30 \% \mathrm{NDF}$. Composition of the major ingredients other than legume silages fed in this trial is in Table 2. Compositions of the legume silages fed in this trial are in Table 4 and of the diets are in Table 5 .

Feeding and sampling of dietary ingredients were conducted as described in trial 1 . Weekly legume silage composites were divided into 2 subsamples. One was stored at $-20^{\circ} \mathrm{C}$ for later extract preparation and a second that was dried at $55^{\circ} \mathrm{C}(48 \mathrm{~h})$. Weekly composites of the corn silage, high-moisture corn, TMR and orts, soy hulls, and soybean meal were dried at $60^{\circ} \mathrm{C}(48 \mathrm{~h})$. Dried legume silages, TMR, corn silage, high-moisture shelled corn, soybean meal, and soy hulls were ground through a 1-mm screen (Wiley mill) and retained for chemical analysis. Dried weekly TMR were also analyzed for total $\mathrm{N}$ using a combustion assay (Leco FP-2000 N Analyzer). Proportions of each ration ingredient on an as-fed basis were adjusted weekly based on these $\mathrm{DM}$ and $\mathrm{N}$ determinations. Intake of
DM was computed based on the $60^{\circ} \mathrm{C}$ DM contents of TMR and orts.

Dried weekly TMR and individual feed ingredients were analyzed for DM, ash and OM, total N, sequentially for NDF and ADF, and legume silages and soybean meal also were analyzed for ADIN (N content of sequential ADF residue) and NDIN as described in trial 1. The TMR composites were also analyzed (Dairyland Laboratories, Arcadia, WI) for indigestible ADF as in trial 1, and for total fat (method 920.39, AOAC International, 1997) and starch (Hall, 2015). Period composites of the legume silage were extracted with distilled water as described by Muck (1987). Extract $\mathrm{pH}$ was determined immediately and extracts were deproteinized (Muck, 1987) and analyzed by flow-injection methods (Lachat Quik-Chem 8000 FIA, Lachat Instruments, Milwaukee, WI) for NPN (Lachat Method 12-107-04-3-b), ammonia by a phenol-hypochlorite method (Lachat Method 18-107-060-1-A) and total free AA (Broderick et al., 2004). Extracts also were analyzed for succinate, lactate, formate, acetate, 
Table 5. Diet composition (trial 2)

\begin{tabular}{|c|c|c|c|c|c|}
\hline \multirow[b]{2}{*}{ Item } & \multicolumn{5}{|c|}{ Legume silage source $^{1}$} \\
\hline & Cov-Alfalfa & BFTL & BFTM & BFTH & BFT mix \\
\hline \multicolumn{6}{|l|}{ Ingredient, $\%$ of $\mathrm{DM}$} \\
\hline Alfalfa & 47.8 & 16.0 & 15.9 & 16.1 & 0.0 \\
\hline Low tannin BFT & 0.0 & 32.0 & 0.0 & 0.0 & 16.0 \\
\hline Normal tannin BFT & 0.0 & 0.0 & 32.2 & 0.0 & 16.1 \\
\hline High tannin BFT & 0.0 & 0.0 & 0.0 & 32.0 & 16.1 \\
\hline Corn silage & 18.2 & 18.1 & 18.1 & 18.1 & 18.1 \\
\hline High-moisture shelled corn & 23.8 & 23.7 & 23.6 & 23.6 & 23.6 \\
\hline Soybean meal & 2.41 & 2.40 & 2.39 & 2.38 & 2.39 \\
\hline Soy hulls & 5.00 & 4.98 & 4.96 & 4.96 & 4.96 \\
\hline Energy Booster $100^{2}$ & 2.00 & 1.99 & 1.98 & 1.98 & 1.98 \\
\hline Sodium bicarbonate & 0.40 & 0.40 & 0.40 & 0.40 & 0.40 \\
\hline Sodium chloride & 0.20 & 0.20 & 0.20 & 0.20 & 0.20 \\
\hline Dicalcium phosphate & 0.10 & 0.10 & 0.10 & 0.10 & 0.10 \\
\hline Vitamins-trace minerals $^{3}$ & 0.12 & 0.12 & 0.12 & 0.12 & 0.12 \\
\hline \multicolumn{6}{|l|}{ Composition } \\
\hline CT concentration, ${ }^{4} \%$ of DM & - & 0.16 & 0.27 & 0.47 & 0.46 \\
\hline $\mathrm{CP}, \%$ of DM & 16.4 & 16.3 & 16.3 & 16.8 & 16.5 \\
\hline Ash, $\%$ of DM & 6.3 & 6.3 & 6.3 & 6.3 & 6.3 \\
\hline Starch, \% of DM & 21.4 & 21.2 & 21.2 & 21.1 & 21.1 \\
\hline $\mathrm{NDF}, \%$ of DM & 30.3 & 29.9 & 30.0 & 30.9 & 30.3 \\
\hline $\mathrm{ADF}, \%$ of $\mathrm{DM}$ & 19.6 & 20.0 & 20.0 & 20.7 & 20.5 \\
\hline NDIN, $\%$ of total $\mathrm{N}$ & 10.8 & 10.4 & 11.8 & 15.0 & 13.2 \\
\hline ADIN, $\%$ of total $\mathrm{N}$ & 3.4 & 3.4 & 3.6 & 3.8 & 3.7 \\
\hline Fraction B $3,{ }^{5} \%$ of total $\mathrm{N}$ & 7.4 & 7.0 & 8.2 & 11.1 & 9.5 \\
\hline Ether extract, \% of DM & 4.9 & 4.8 & 4.8 & 4.8 & 4.7 \\
\hline $\mathrm{NFC},{ }^{6} \%$ of DM & 43.9 & 44.4 & 44.5 & 43.7 & 44.4 \\
\hline \multicolumn{6}{|c|}{$\begin{array}{l}{ }^{1} \mathrm{BFT}=\text { birdsfoot trefoil; BFTL }=\text { low tannin birdsfoot trefoil; BFTM }=\text { medium tannin birdsfoot trefoil } \\
\text { BFTH = high tannin birdsfoot trefoil; Cov-Alfalfa }=\text { covariate-alfalfa diet. }\end{array}$} \\
\hline \multicolumn{6}{|c|}{${ }^{2}$ Milk Specialties, Eden Prairie, Minnesota. } \\
\hline \multirow{3}{*}{\multicolumn{6}{|c|}{$\begin{array}{l}{ }^{3} \text { Provided (per kilogram of DM): } 56 \mathrm{mg} \text { of } \mathrm{Zn}, 46 \mathrm{mg} \text { of } \mathrm{Mn}, 22 \mathrm{mg} \text { of Fe, } 12 \mathrm{mg} \text { of } \mathrm{Cu}, 0.9 \mathrm{mg} \text { of I, } 0.4 \mathrm{mg} \text { o } \\
\mathrm{Co}, 0.3 \mathrm{mg} \text { of Se, } 6,440 \mathrm{IU} \text { of vitamin } \mathrm{A}, 2,000 \mathrm{IU} \text { of vitamin } \mathrm{D}, 16 \mathrm{IU} \text { of vitamin E, and } 12 \mathrm{mg} \text { of monensin. } \\
{ }^{4} \text { Condensed tannin }(\mathrm{CT} \text { ) concentration of diets computed from CT content of ensiled forages (Table } 4 \text { ). } \\
{ }^{5} \text { Fraction B3 = NDIN - ADIN. }\end{array}$}} \\
\hline & & & & & \\
\hline & & & & & \\
\hline${ }^{6}$ Computed according to NRC & & & & & \\
\hline
\end{tabular}

propionate, butyrate, 1,2-propanediol, ethanol, and 2,3-butanediol using HPLC methodology (Muck and Dickerson, 1988).

Cows were injected with rBST and milked as described in trial 1 . Midway through wk 1 and 2 of the covariate period and through wk 2, 4, 6, 8, 10, and 12 of the experimental periods, milk samples were collected from each cow at an a.m. and p.m. milking, preserved with 2-bromo-2-nitropropane-1,3-diol, stored at $4^{\circ} \mathrm{C}$ until analyzed for fat, protein, lactose, SNF, and MUN and ECM yield computed as described in trial 1. Cows were weighed on 3 consecutive days at the start and at the end of wk 4, 8, and 12 to yield 3 observations per cow of BW change over the trial.

At the end of wk 4, 8, and 12, spot urine and fecal samples also were collected, processed and analyzed as described in trial 1 except that urine was also analyzed for urea $\mathrm{N}$ using an automated colorimetric assay (Broderick and Clayton, 1997) adapted to flowinjection (Lachat Quik-Chem 8000 FIA, Lachat Instruments, Loveland, CO). Ruminal fluid was collected via ruminal cannulas on the last day of wk 4,8 , and 12 at $0,1,2,4,6,8$, and $12 \mathrm{~h}$ after feeding from 4 sites in the ventral rumen. Samples were filtered through 2 layers of cheesecloth, the $\mathrm{pH}$ measured immediately by glass electrode, and then preserved by adding 0.2 $\mathrm{mL}$ of $50 \%$ ( $\mathrm{vol} / \mathrm{vol}$ ) $\mathrm{H}_{2} \mathrm{SO}_{4}$ to $10-\mathrm{mL}$ ruminal fluid and stored at $-20^{\circ} \mathrm{C}$ until analyzed. After thawing and centrifugation $\left(15,300 \times g\right.$ for 20 min at $\left.4^{\circ} \mathrm{C}\right)$, ruminal supernatants were analyzed by flow-injection methods for ammonia and total free AA as described for legume silage extracts. Individual and total ruminal VFA were determined in supernatants using the HPLC methodology also applied to silage organic acids (Muck and Dickerson, 1988). This method did not resolve isovalerate and 2-methyl butyrate, which are reported as isovalerate plus 2-methylbutyrate.

\section{Statistical Analyses}

Composition data from the 4 legume silages fed in both trials were analyzed with the mixed procedures of 
SAS Institute Inc. (2013) using a model that included trial week and silage source. Production data from trial 1 were analyzed as a replicated $4 \times 4$ Latin square using the mixed procedures of SAS Institute Inc. (2013). A single mean observation was computed for each production trait for each cow over the last 2 wk of each period $(\mathrm{n}=32)$. Model sums of squares from the data were separated into overall mean, cow(within square), square, period, treatment (effect of silage source), square $\times$ treatment interaction, and overall error. All variables were considered fixed, except cow (within square) and overall error, which were considered random. Least squares means for legume forage sources are reported. Orthogonal contrasts were used to test for differences between the AS diet versus the 3 BFT diets, and for linear and quadratic effects of increasing CT content in the BFT silages. For all statistical analyses, significance was declared at $P \leq 0.05$ and trends at 0.05 $<P \leq 0.10$.

In trial 2, production data from experimental wk 2 were discarded to allow for transition from the covariate period. Statistical analyses of all data except BW change, MUN, nutrient efficiencies, apparent digestibility, excretion traits, and ruminal metabolite concentrations were conducted with the mixed procedures of SAS Institute Inc. (2013) using a model including a single covariate mean for each trait plus cow block $(\mathrm{n}=10)$, legume forage source $(\mathrm{n}=5)$, week $(\mathrm{n}=5)$, and the interaction of silage $\times$ week. The same approach was used for BW change, MUN, nutrient efficiencies, apparent digestibility, excretion traits, and ruminal metabolite concentrations except the model did not include the covariate and $\mathrm{n}=3$ (BW change, apparent digestibility, excretion traits, ruminal metabolite concentrations) or $\mathrm{n}=5$ (MUN, nutrient efficiencies) for week. Both models included AR(1) structure for repeated measures over time. All variables were considered fixed, except cow, whole plot error, and subplot error, which were considered random. Least squares means for legume forage sources are reported. Orthogonal contrasts were used to test for differences between the AS diet versus the $4 \mathrm{BFT}$ diets, between the mixed BFT diet versus the other $3 \mathrm{BFT}$ diets, and for linear and quadratic effects of increasing CT content in the BFT forages. For all statistical analyses, significance was declared at $P \leq 0.05$ and trends at $0.05<P \leq 0.10$.

\section{RESULTS}

\section{Trial 1}

As anticipated, CT concentrations in the BFT forages, determined by a butanol-HCl assay (Grabber, 2008), increased in a step-wise manner from about 0.6 to $1.7 \%$ of DM (Table 1); this was dictated by the selection process of Miller and Ehlke (1996) that generated the BFT populations used in this trial. As well as containing more ash, the AS fed in this trial was substantially higher in CP than the 3 BFT silages; thus, the AS diet averaged about 2 percentage units higher in $\mathrm{CP}$ than the BFT diets (Table 3). The BFTH silage was lowest in $\mathrm{CP}$ among the legume forages fed in this study (Table 1). The NDF content of BFTM was greater than the other silages; BFTM also had greater ADF content than BFTL, whereas BFTH was intermediate. The AS was lowest in ADF concentration. Although ADIN was not different among the legume silages, both NDIN and fraction B3 (NDIN - ADIN) were lowest in AS and increased in the BFT silages in parallel with CT concentration. Unfortunately, data on silage $\mathrm{pH}$ and NPN concentration are not available from this trial. An analysis of silage metabolites indicated that all BFT silages fermented well, whereas AS had a high acetate concentration and sufficient butyrate to indicate suboptimal silage fermentation (Table 1).

Production results from trial 1 indicated that DMI was greater on the diets containing BFT silages versus AS, with linear and quadratic effects of CT concentration indicating greatest DMI on BFTM (Table 6). As a result, cows lost BW when fed the AS diet while cows gained about $0.5 \mathrm{~kg}$ of $\mathrm{BW} / \mathrm{d}$ when fed $\mathrm{BFT}$ silage diets. Although milk yield was not different between $\mathrm{AS}$ and BFT diets, there were trends for quadratic and linear effects of CT content in BFT on, respectively, milk yield and ECM yield. Moreover, quadratic effects of $\mathrm{CT}$ content in BFT on ECM and fat secretion also were detected, indicating greater yield on BFTM than on the other 2 BFT diets, in parallel with DMI. However, apparent feed efficiencies (milk/DMI and ECM/ DMI) were greater on AS. This result was, of course, confounded by mobilization of body nutrients to support milk production on AS compared with nutrient deposition on the 3 BFT diets. A trend was observed for greater milk protein concentration on the $3 \mathrm{BFT}$ diets versus the AS diet; moreover, true protein yield averaged $50 \mathrm{~g} / \mathrm{d}$ more the BFT diets than on AS. Furthermore, a linear effect on true protein secretion was observed, indicating protein yield declined with increasing CT concentration in BFT. A trend was observed for milk lactose concentration to be greater on AS, but no difference in lactose yield was observed. The trend for greater SNF yield on the BFT silages versus AS paralleled that observed for true protein yield. Concentrations of MUN were 1.8 to 2.6 units lower on the BFT diets versus the diet containing AS; MUN among the 3 BFT diets declined linearly with CT content. Apparent $\mathrm{N}$-efficiency was greater on the BFT diets, averaging $27 \%$ compared with about $25 \%$ on AS; this result is, 
Table 6. Production of lactating cows fed alfalfa silage or birdsfoot trefoil silage with varying contents of condensed tannins (trial 1)

\begin{tabular}{|c|c|c|c|c|c|c|c|c|}
\hline Item & \multicolumn{4}{|c|}{ Legume silage source $^{1}$} & $\mathrm{SEM}^{2}$ & \multicolumn{3}{|c|}{ Orthogonal contrast $^{3}$} \\
\hline DMI, $\mathrm{kg} / \mathrm{d}$ & 25.4 & 27.6 & 28.2 & 26.7 & 0.57 & $<0.01$ & 0.02 & 0.01 \\
\hline Milk, kg/d & 41.7 & 42.4 & 43.2 & 41.8 & 0.92 & 0.24 & 0.40 & 0.09 \\
\hline Milk/DMI & 1.65 & 1.53 & 1.54 & 1.57 & 0.025 & $<0.01$ & 0.11 & 0.58 \\
\hline $\mathrm{ECM}, \mathrm{kg} / \mathrm{d}$ & 40.5 & 41.3 & 42.2 & 39.5 & 1.05 & 0.51 & 0.07 & 0.04 \\
\hline Fat, $\mathrm{kg} / \mathrm{d}$ & 1.66 & 1.65 & 1.71 & 1.57 & 0.054 & 0.76 & 0.13 & 0.05 \\
\hline True protein, \% & 3.07 & 3.14 & 3.10 & 3.10 & 0.038 & 0.10 & 0.16 & 0.39 \\
\hline True protein, $\mathrm{kg} / \mathrm{d}$ & 1.26 & 1.33 & 1.33 & 1.27 & 0.034 & 0.02 & 0.05 & 0.20 \\
\hline Lactose, $\%$ & 4.80 & 4.76 & 4.76 & 4.77 & 0.037 & 0.06 & 0.71 & 0.92 \\
\hline Lactose, $\mathrm{kg} / \mathrm{d}$ & 1.97 & 2.04 & 2.07 & 1.98 & 0.053 & 0.14 & 0.22 & 0.16 \\
\hline SNF, $\%$ & 8.76 & 8.78 & 8.75 & 8.75 & 0.053 & 0.92 & 0.31 & 0.46 \\
\hline $\mathrm{SNF}, \mathrm{kg} / \mathrm{d}$ & 3.60 & 3.74 & 3.78 & 3.62 & 0.092 & 0.07 & 0.12 & 0.15 \\
\hline
\end{tabular}

${ }^{1} \mathrm{BFTL}=$ low tannin birdsfoot trefoil; BFTM = medium tannin birdsfoot trefoil; BFTH $=$ high tannin birdsfoot trefoil.

${ }^{2}$ Standard error of the LSM.

${ }^{3} \mathrm{~A}$ vs. $\mathrm{B}=$ alfalfa silage versus all 3 birdsfoot trefoil silages; Lin = linear effect of condensed tannins in the 3 individual birdsfoot trefoil silages; Quad = quadratic effect of condensed tannins in the 3 individual birdsfoot trefoil silages.

of course, confounded by the higher $\mathrm{CP}$ content of the AS diet.

Apparent digestibilities of DM, OM, N, NDF and $\mathrm{ADF}$ were all greater on $\mathrm{AS}$ than on the $3 \mathrm{BFT}$ diets (Table 7). However, linear (NDF digestibility) and quadratic (NDF and ADF digestibility) effects for $\mathrm{CT}$ concentration in BFT forages were observed, suggesting that fiber digestion did not decline directly with increasing CT concentration. Apparent fiber digestibility among the BFT diets is interesting in that it was numerically similar on BFTL and BFTH, and lowest on BFTM.

Lower DMI on AS compensated for its greater CP content, and as a result, there was only a trend for greater $\mathrm{N}$ intake on the AS diet (Table 7). Although no differences were present in the amount of fecal $\mathrm{N}$ excretion, fecal $\mathrm{N}$ as a proportion of $\mathrm{N}$ intake was greater on $\mathrm{BFT}$ diets than on the AS diet, reflecting the lower apparent N digestibility on BFT. However, both the amount and proportion of $\mathrm{N}$ intake excreted as urinary

Table 7. Apparent digestibility and N-metabolism of lactating cows fed alfalfa silage or birdsfoot trefoil silage with varying contents of condensed tannins (trial 1)

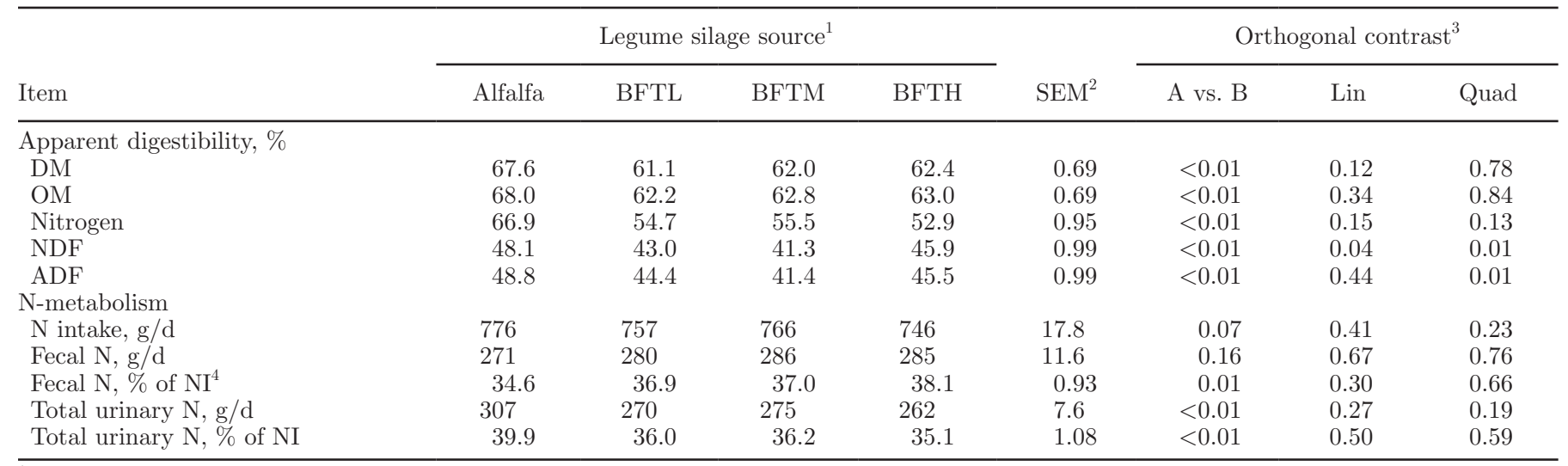

${ }^{1} \mathrm{BFTL}=$ low tannin birdsfoot trefoil; BFTM = medium tannin birdsfoot trefoil; BFTH $=$ high tannin birdsfoot trefoil.

${ }^{2}$ Standard error of the LSM.

${ }^{3} \mathrm{~A}$ vs. $\mathrm{B}=$ alfalfa silage versus all 3 birdsfoot trefoil silages; Lin = linear effect of condensed tannins in the 3 individual birdsfoot trefoil silages; Quad $=$ quadratic effect of condensed tannins in the 3 individual birdsfoot trefoil silages.

${ }^{4} \mathrm{NI}=\mathrm{N}$ intake. 
$\mathrm{N}$ was lower with BFT silage versus AS. In this trial, milk protein secretion was greater in the presence of low to intermediate concentrations of $\mathrm{CT}$.

\section{Trial 2}

Concentrations of CT determined by the butanol$\mathrm{HCl}$ assay in the BFT forages fed in this trial were comparable to the first study, ranging from 0.5 to $1.5 \%$ of DM (Table 4). Although significant, differences in $\mathrm{CP}$ among the 4 silages were small and much more uniform than in trial 1. Fiber contents and $\mathrm{N}$ fractions as proportion of total $\mathrm{N}$ in $\mathrm{AS}$ and BFT were also similar, but BFTH had higher levels of NDF, ADF, NDIN, fraction B3, and ADIN and lower levels of total soluble $\mathrm{N}$ and NPN than other silages. The BFTM silage had intermediate amounts of the various $\mathrm{CP}$ fractions, but its NDF and ADF contents were similar to AS and BFTL. Silages made from BFTM and BFTH tended to have a lower free AA than AS and BFTL. Although silage $\mathrm{pH}$ values were typical for legume silages, $\mathrm{pH}$ was lower in the BFTL and BFTM silages. Differences also were observed in concentrations of fermentation metabolites among the silages (Table 4). Lactate and 2,3-butandiol concentrations were higher in BFTL and BFTH silages, those containing lower DM, possibly due to greater fermentation rates than in the other 2 silages. Both acetate and succinate were lower in BFTL and BFTM silages. Ethanol tended to be reduced in the BFT silages, but concentrations of both ethanol and butyrate were very low, indicating excellent fermentation characteristics for all 4 silages. The metabolite 1,2-propanediol was found in almost all AS samples but was below detectable limits for the 3 BFT silages.

A trend was observed for greater DMI and milk yield on the BFT diets versus the AS diet in trial 2 (Table 8). Unlike trial 1, no differences were present in BW change among diets, which averaged about $0.6 \mathrm{~kg}$ gain $/ \mathrm{d}$, and except for a trend for lower ECM/DMI on the mixed $\mathrm{BFT}$ diet versus the other $3 \mathrm{BFT}$ diets, no differences were observed in milk and ECM secretion per unit of DMI. A linear effect, and a trend for a quadratic effect, of $\mathrm{CT}$ content of BFT forages were observed for DMI. The DMI responses were reflected in linear effects on yield of milk, ECM, fat, true protein, lactose, and SNF, indicating reductions with increasing $\mathrm{CT}$ concentration. Milk concentrations of fat, lactose, and SNF were not affected by diet; however, milk true protein was lower on the mixed BFT diet versus the other $3 \mathrm{BFT}$ diets. Concentrations of MUN were greater on AS versus the 4 BFT diets and lower on the BFT mix versus the other 3 BFT diets. Despite these effects on MUN, apparent N-efficiency was not altered by source of dietary legume silage in this study.

Unlike trial 1, only a trend was detected for lower apparent $\mathrm{N}$ digestibility on the BFT diets versus AS and apparent digestibility of DM, OM, and ADF was not different among cows fed diets containing AS versus the BFT forages (Table 9). However, apparent digestibility of all 5 nutrients measured was lower on the

Table 8. Production of lactating cows fed alfalfa silage or birdsfoot trefoil silage with varying contents of condensed tannins (trial 2)

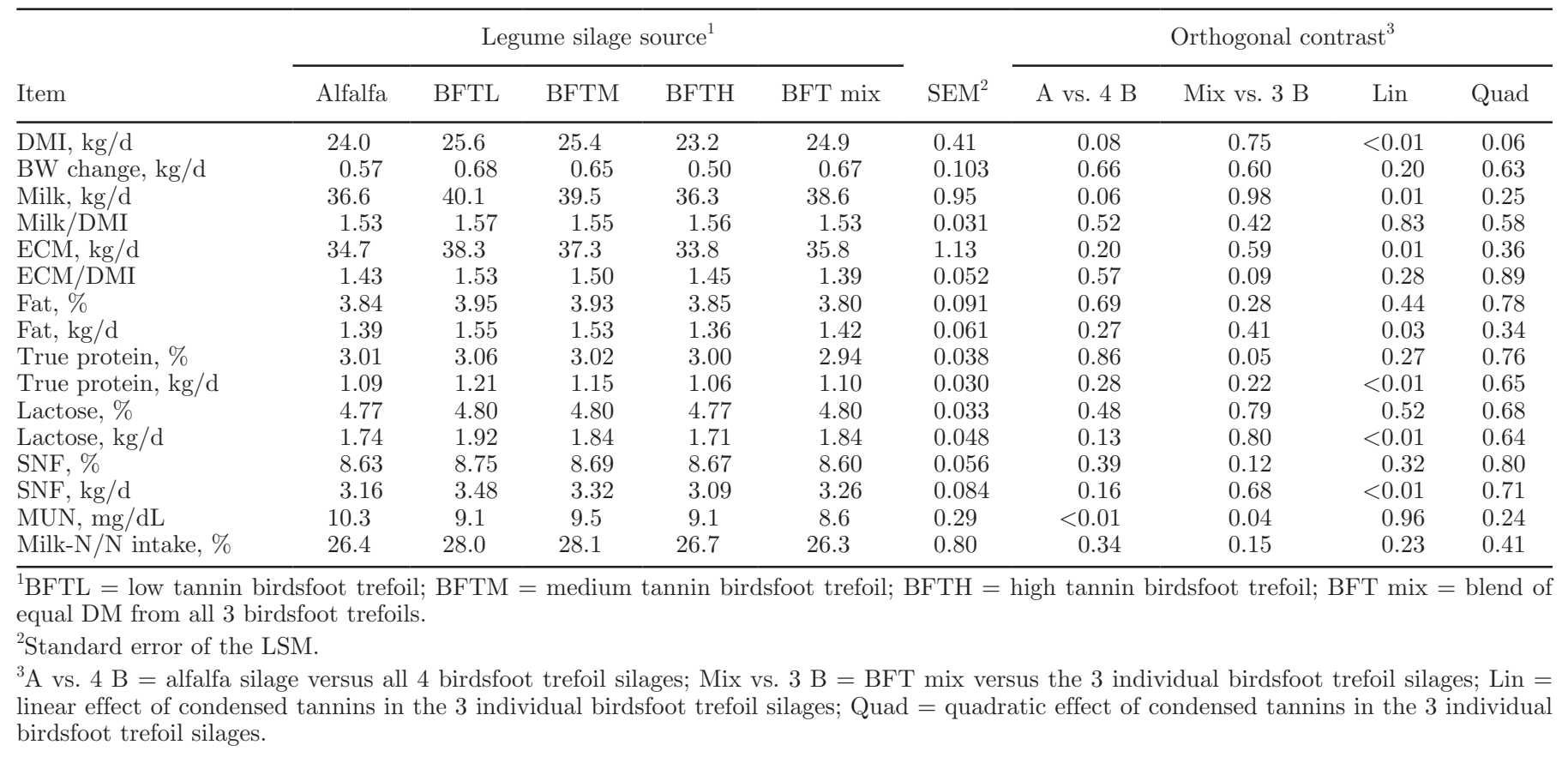


Table 9. Apparent digestibility and N-metabolism of lactating cows fed alfalfa silage or birdsfoot trefoil silage with varying contents of condensed tannins (trial 2)

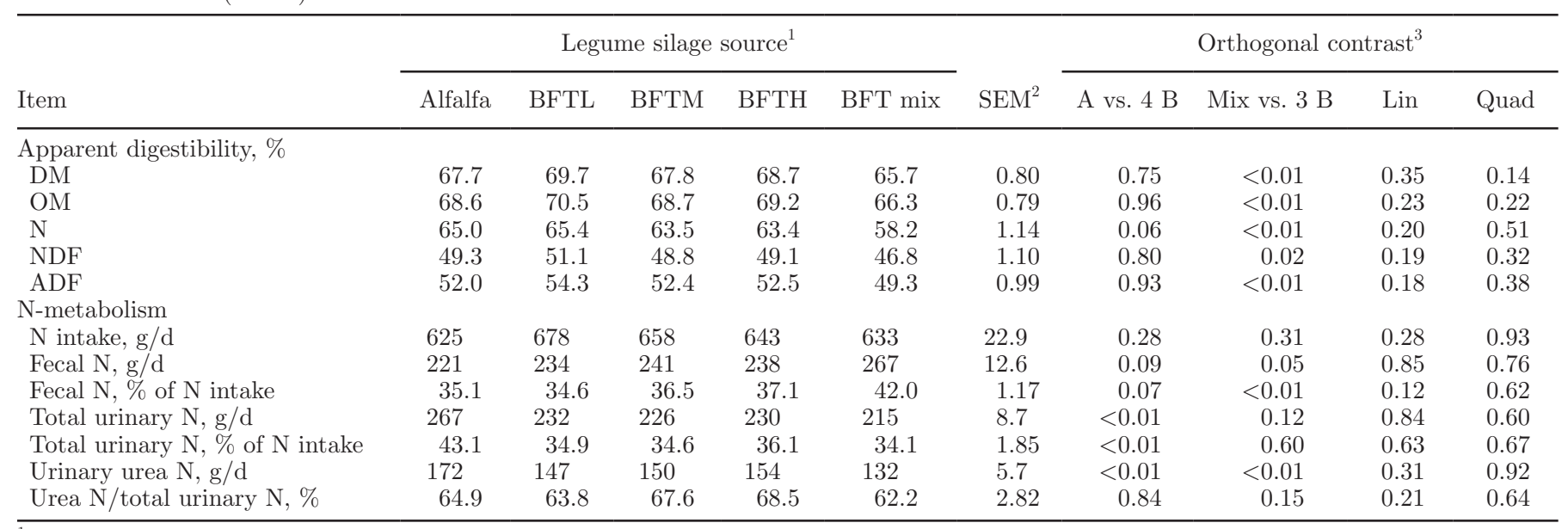

${ }^{1} \mathrm{BFTL}=$ low tannin birdsfoot trefoil; BFTM = medium tannin birdsfoot trefoil; BFTH = high tannin birdsfoot trefoil; BFT mix $=$ blend of equal DM from all 3 birdsfoot trefoils.

${ }^{2}$ Standard error of the LSM.

${ }^{3} \mathrm{~A}$ vs. $4 \mathrm{~B}=$ alfalfa silage versus all 4 birdsfoot trefoil silages; Mix vs. $3 \mathrm{~B}=$ BFT mix versus the 3 individual birdsfoot trefoil silages; Lin $=$ linear effect of condensed tannins in the 3 individual birdsfoot trefoil silages; Quad = quadratic effect of condensed tannins in the 3 individual birdsfoot trefoil silages.

BFT mix versus the other 3 BFT diets. Trends were detected for lower amount and proportion (of $\mathrm{N}$ intake) of fecal N excreted on AS versus BFT. However, the amount and proportion of urinary $\mathrm{N}$ excretion, as well as urinary urea $\mathrm{N}$ excretion, were greater on $\mathrm{AS}$ than on the BFT diets. Amount and proportion of fecal $\mathrm{N}$ excretion were greater on the diet containing the BFT mix compared with the other BFT diets, an effect that was not explained by dietary CT concentrations, which were similar on the diets containing BFTH and the BFT mix (Table 5). Urinary excretion of urea $\mathrm{N}$ was also lower on the BFT mix. No linear or quadratic effects of CT concentration on digestibility or N excretion results were detected in trial 2. As was observed in trial 1 , the overall effect of dietary CT in this study was to divert excretory $\mathrm{N}$ from urine to feces, but without a reduction in apparent nutrient digestion in this study.

Table 10. Ruminal metabolite concentrations in lactating cows fed alfalfa silage or birdsfoot trefoil silage with varying contents of condensed tannins (trial 2)

\begin{tabular}{|c|c|c|c|c|c|c|c|c|c|c|}
\hline Item & \multicolumn{5}{|c|}{ Legume silage source ${ }^{1}$} & $\mathrm{SEM}^{2}$ & \multicolumn{4}{|c|}{ Orthogonal contrast $^{3}$} \\
\hline $\mathrm{pH}$ & 6.42 & 6.32 & 6.47 & 6.49 & 6.52 & 0.074 & 0.75 & 0.36 & 0.17 & 0.52 \\
\hline Total AA, mM & 3.28 & 2.93 & 3.10 & 3.35 & 3.14 & 0.237 & 0.61 & 0.95 & 0.28 & 0.90 \\
\hline Acetate, $\mathrm{m} M$ & 65.2 & 64.3 & 60.1 & 58.6 & 55.2 & 5.81 & 0.44 & 0.44 & 0.53 & 0.86 \\
\hline Propionate, $\mathrm{m} M$ & 18.4 & 16.9 & 18.0 & 17.6 & 15.8 & 2.32 & 0.64 & 0.56 & 0.83 & 0.79 \\
\hline Valerate, $\mathrm{m} M$ & 0.88 & 0.68 & 0.52 & 0.56 & 0.45 & 0.146 & 0.11 & 0.47 & 0.61 & 0.60 \\
\hline Isobutyrate, $\mathrm{m} M$ & 2.07 & 1.97 & 1.54 & 0.65 & 1.30 & 0.510 & 0.34 & 0.87 & 0.21 & 0.79 \\
\hline Isovalerate +2 -methyl butyrate, $\mathrm{m} M$ & 2.65 & 2.93 & 1.64 & 0.84 & 1.00 & 0.809 & 0.32 & 0.45 & 0.16 & 0.83 \\
\hline $\mathrm{BCVFA},{ }^{4} \mathrm{~m} M$ & 4.72 & 4.89 & 3.18 & 1.48 & 2.29 & 0.966 & 0.19 & 0.48 & 0.08 & 1.00 \\
\hline Total VFA, $\mathrm{m} M$ & 101.6 & 98.5 & 91.3 & 86.1 & 81.9 & 9.40 & 0.41 & 0.48 & 0.56 & 0.90 \\
\hline
\end{tabular}

${ }^{1} \mathrm{BFTL}=$ low tannin birdsfoot trefoil; BFTM = medium tannin birdsfoot trefoil; BFTH $=$ high tannin birdsfoot trefoil; BFT mix $=$ blend of equal DM from all 3 birdsfoot trefoils.

${ }^{2}$ Standard error of the LSM.

${ }^{3} \mathrm{~A}$ vs. $4 \mathrm{~B}=$ alfalfa silage versus all 4 birdsfoot trefoil silages; Mix vs. $3 \mathrm{~B}=\mathrm{BFT}$ mix versus the 3 individual birdsfoot trefoil silages; Lin $=$ linear effect of condensed tannins in the 3 individual birdsfoot trefoil silages; Quad = quadratic effect of condensed tannins in the 3 individual birdsfoot trefoil silages.

${ }^{4}$ Total branched-chain VFA (isobutyrate plus isovalerate +2 -methyl butyrate). 
Ruminal metabolite concentrations observed during trial 2 are in Table 10. No significant effects were observed on any ruminal metabolite except for a linear reduction in ammonia concentration, and a trend for linear reduction in total branched-chain VFA (BCVFA), with increasing CT content in BFT forages.

\section{DISCUSSION}

Condensed tannins in $\mathrm{BFT}$ precipitate proteins and reduce proteolysis during forage conservation and rumen fermentation (Albrecht and Muck, 1991; Broderick and Albrecht, 1997; Grabber and Coblentz, 2009; Coblentz and Grabber, 2013). Thus, as expected, total soluble CP and NPN declined, and NDIN and fraction B3 (NDIN - ADIN) increased, as CT concentrations increased from 0.5 to $1.5 \%$ of DM in BFT silages fed in trial 2 (Table 4). Although data on soluble $\mathrm{N}$ fractions are not available from trial 1, NDIN and fraction B3 in that study also increased modestly as CT concentrations increased from 0.6 to $1.7 \%$ of DM (Table 1 ). These patterns and comparable step-wise increases in $\mathrm{CT}$ concentration in BFTL, BFTM, and BFTH forages suggested that there should have been similar effects of CT on CP utilization in both trials. Furthermore, presence of CT was expected to decrease ruminal protein degradation (Broderick and Albrecht, 1997). Patterns of reduced ammonia and BCVFA concentrations in the rumen were observed in trial 2 with increasing $\mathrm{CT}$ concentration in BFT (Table 10). The BCVFA are formed largely from microbial catabolism of the branched-chain AA (Val, Ile, and Leu) released during protein breakdown (Van Soest, 1994) and ammonia is also a product of ruminal protein degradation. Based on these shifts in protein fractions and rumen metabolites, we expected that $\mathrm{CT}$ in BFT silages in trial 1 and especially trial 2 would improve MP supply and, relative to AS, elevate production of milk and milk components in lactating cows.

Replacing dietary AS with CT containing BFT forage numerically increased yield of milk and ECM in both trials and significantly increased true protein yield in trial 1 (Table 6). Although yields of other milk components on diets formulated with BFT silages were similar to those on AS, estimated N-efficiency was greater on the BFT silages than on AS in trial 1. Furthermore, MUN was reduced on all BFT-containing diets relative to AS in both trials. The MUN responses reflected relative improvement in N-utilization with the feeding of BFT silages (Broderick and Clayton, 1997; Nousiainen et al., 2004) and are generally in agreement with our previous observations (Hymes-Fecht et al., 2013). Although these findings confirmed our hypothesis that $\mathrm{CT}$ in BFT diets can improve MP supply and lactation performance of dairy cattle, production responses to CT were much larger and maximized by feeding diets formulated with BFTH in our previous work (HymesFecht et al., 2013).

In trial 1 , effects on production were due in part to feed intake averaging $2.1 \mathrm{~kg} / \mathrm{d}$ more on BFT versus AS; increased DMI was accompanied by reduced apparent DM efficiency on all 3 BFT diets (Table 6). Effects on feed intake were reflected in a mean $\mathrm{BW}$ gain of 0.48 $\mathrm{kg} / \mathrm{d}$ on BFT versus a BW loss of $0.14 \mathrm{~kg} / \mathrm{d}$ on AS. Despite the estimated differences in digestibility found in trial 1 (Table 7), intake of apparently digested OM was $17.3 \mathrm{~kg} / \mathrm{d}$ on AS versus a mean of $17.2 \mathrm{~kg} / \mathrm{d}$ on the 3 BFT diets. The BW loss on AS in trial 1 was surprising in view of the similar consumption of digested OM and yield of ECM relative to the BFT diets (Table 6). Cows were also in mid-lactation during the trial and should have been gaining weight to replace the $\mathrm{BW}$ and BCS loss occurring in early lactation; hence, the weight loss observed on the AS diet would not be sustainable. A possible explanation is that an inadequate MP supply may have impaired $\mathrm{NE}_{\mathrm{L}}$ utilization on the $\mathrm{AS}$ diet. Effective dietary $\mathrm{NE}_{\mathrm{L}}$ value computed from milk ECM yield (0.749 Mcal/kg; Krause and Combs, 2003), plus BW change $(6.98 \mathrm{Mcal} / \mathrm{kg}$ change in $\mathrm{EBW}$; NRC, $2001)$ and maintenance $\left(0.080 \mathrm{Mcal} / \mathrm{kg} \mathrm{BW}^{0.75}\right.$ at mean BW of $670 \mathrm{~kg}$; NRC, 2001), was $1.57 \mathrm{Mcal} / \mathrm{kg}$ of DM for the AS diet and $1.60 \mathrm{Mcal} / \mathrm{kg}$ of DM for the $3 \mathrm{BFT}$ diets. Although this suggests no difference in $\mathrm{NE}_{\mathrm{L}}$ utilization in trial 1 , several literature reports document that improved MP status improved $\mathrm{NE}_{\mathrm{L}}$ utilization: Brun-Lafleur et al. (2010) observed a linear increase in milk and fat yield as MP supply increased in diets formulated to be adequate and equal in energy supply. Auldist et al. (2014) reported that replacing starchy concentrates with canola meal in supplements fed to grazing dairy cows increased ECM yield. A similar pattern of DMI was observed in trial 2 with no influence on BW gain and feed efficiency (Table 8). Except for the diet containing the mixture of all 3 BFT silages, which was lower than the other BFT diets for all nutrients measured, no differences in apparent digestibility were observed among diets containing AS and BFT in trial 2 (Table 9).

Several differences were present in chemical composition among the silages fed in these studies, nearly all of which reached significance at $P \leq 0.01$ (Tables 1 and 4). However, composition of the AS and all BFT silages fed in both trials fell within normal ranges for early-cut legume forages (McDonald et al., 1991; NRC, 2001). For example, NDF and ADF contents ranged from, respectively, 36 to $38 \%$ and 27 to $30 \%$ (trial 1; Table 1), and from 34 to $38 \%$ and 26 to $30 \%$ (trial 2; Table 4). Moreover, fermentation metabolites, particularly very 
low concentrations of ethanol and butyrate (Table 4), indicated that the 4 silages fed in trial 2 were of excellent quality. Most noteworthy of the differences between AS and the BFT silages fed in these studies was the excessively high CP content of AS and the lower apparent digestibility of BFT silages fed in trial 1. Although data on NPN contents were not available for trial 1, it was likely that this AS contained large amounts of NPN, which would depress utilization of the CP in that diet. Based on the high acetate concentrations and the presence of butyrate in AS, suboptimal ensiling may have contributed to lower intake and BW losses of cows fed AS diets in trial 1. The AS also had a higher total silage acid content than the BFT silages (10.7 vs. $6.4 \%$ DM) that may have lowered AS intake. The acetate and butyrate concentrations in AS remained constant during the course of trial 1 (data not shown), indicating that AS did not undergo typical pattern of clostridial fermentation (Pahlow et al., 2003). So it appears that the suboptimal fermentation of AS was due to competition from other non-lactic acid bacterial species early in the ensiling process. Moreover, the greater lactate concentrations in BFT silages are indicative of better fermentation of those forages in the silo.

Although differing in CT content, other plant-related factors probably contributed to the uniformly lower apparent digestibility of $\mathrm{N}$ and other constituents in all BFT diets relative to the AS diet in trial 1 (Table 7 ). When grown and harvested concurrently, the BFT populations used in this study normally had similar to somewhat lower $\mathrm{CP}$ levels and DM digestibility and lower NDF levels than alfalfa under a conservation harvest management (Grabber and Coblentz, 2009; Grabber et al., 2014, 2015). Because forage quality of BFT and alfalfa declines with plant maturity (Cassida et al., 2000), the lower CP content, lower DM digestibility, and higher NDF content of BFT silages suggest they were harvested at a more mature growth stage than AS fed in trial 1 (Table 1). Furthermore, the BFT silages and AS used in trial 1 were harvested from different cuttings in 2004 and previous work has shown that growth environment can cause considerable shifts in the nutritive value of these forages (Cassida et al., 2000; Grabber et al., 2014, 2015). In particular, the second cutting of BFT used in trial 1 was grown under warm temperatures with ample precipitation that tend to depress forage quality (Petit et al., 1992; Buxton and Fales, 1994), and this may have contributed to the relatively low digestibility of BFT silages. These differences between BFT silages and AS likely impaired our ability to assess CT effects on $\mathrm{N}$ utilization and animal performance in trial 1. In contrast, BFT and AS taken from different cuttings in trial 2 (Table 9) and from the same cutting in the Hymes-Fecht et al. (2013) trial were quite uniform for $\mathrm{CP}$ and fiber content and for $\mathrm{DM}, \mathrm{OM}, \mathrm{NDF}$, and ADF digestibility. This suggests that trial 2 and the Hymes-Fecht et al. (2013) trial would provide a relatively robust test of CT effects on $\mathrm{N}$ utilization animal performance. In addition to these trials, other studies have indicated that $\mathrm{CT}$ in BFT reduced $\mathrm{N}$ degradability but had little or no effect on OM and fiber digestion (Waghorn et al., 1987; Chiquette et al., 1989; Waghorn and Shelton, 1997), suggesting that effects of the CT in BFT on energy digestibility would be minor.

Total CT concentrations in trial 2 ranged from about $0.5 \%$ in BFTL to $1.5 \%$ of DM in BFTH silages (Tables 4 ), which were comparable to levels found in the previous trial utilizing a different cutting of these same forages (Hymes-Fecht et al., 2013). Among BFT diets in trial 2, BFTL produced numerically the highest yield of milk and ECM that was $3.5 \mathrm{~kg} / \mathrm{d}$ greater than the AS diet. Moreover, linear contrasts in trial 2 indicated that yield of milk and milk components actually declined as CT concentration increased above that found in the BFTL forage. These results were surprising in that milk and component yields in the Hymes-Fecht et al. (2013) trial were greatest on the diet containing BFTH although production responses were greater on all 3 BFT silages than on AS. Cows fed BFT silage in place of AS in the Hymes-Fecht et al. (2013) trial also had greater $\mathrm{N}$ use-efficiency and more modest reductions in MUN and urinary $\mathrm{N}$ excretion than we observed in trial 2 . Reductions in urinary $\mathrm{N}$ and urea associated with feeding BFT are beneficial for reducing ammonia emissions from manure (Misselbrook et al., 2005).

An important difference among these experiments was that diets contained $60 \%$ legume silage in the HymesFecht et al. (2013) trial versus $48 \%$ legume silage in trial 2. Moreover, 3 of the diets fed in trial 2 contained only $32 \%$ BFT silage plus $16 \%$ AS. Furthermore, trial 1 and the Hymes-Fecht et al. (2013) were reversal studies whereas trial 2 was a repeated measures study. Thus, differences in diet formulation and experimental design between trials may partly account for the inconsistent production response of cows fed BFT with differing levels of $\mathrm{CT}$. It was also noted that the BFT silages fed in the earlier experiment did not contain higher proportions of NDIN and fraction B3, and lower proportions of NPN than the AS control (Hymes-Fecht et al., 2013). However, NPN values reported for the earlier experiment may not have adequately reflected how CT reduced N solubility in BFT silages because subsequent analysis of these silages by the borophosphate-buffer method of Grabber (2008) indicated that soluble $\mathrm{N}$ as a proportion of total $\mathrm{N}$ averaged $61.6 \%$ for AS compared with $64.4 \%$ for BFTL, $55.9 \%$ for BFTM, and $53.9 \%$ for BFTH. Furthermore, NDIN and ADIN were prob- 
ably underestimated in the Hymes-Fecht et al. (2013) trial because sodium sulfite added to the neutral detergent solution would remove most of the CT-protein complexes from fiber residues (Krueger et al., 1999). Indeed, reanalysis of silages from the Hymes-Fecht et al. (2013) trial without sodium sulfite revealed that NDIN as a proportion of $\mathrm{N}$ increased modestly from $9.2 \%$ in $\mathrm{AS}$ and $8.8 \%$ in BFTL to $11.6 \%$ in BFTM and $12.5 \%$ in BFTH, whereas ADIN as a proportion of $\mathrm{N}$ increased from $3.8 \%$ in AS to $4.8 \%$ in BFTL, $5.7 \%$ in BFTM, and $6.0 \%$ in BFTH. Thus, CT did indeed reduce soluble $\mathrm{N}$ and increased fiber-associated $\mathrm{N}$ fractions in the Hymes-Fecht et al. (2013) trial, but NDIN levels for reanalyzed BFT silages were much lower than BFT silages from trial 2 (Table 4), suggesting that CT may have been less strongly bound to protein. Longer storage of BFT silages for trial $2(>1.5 \mathrm{yr})$ versus the Hymes-Fecht et al. (2013) trial (0.5 yr) may have influenced the strength of CT-protein complex formed in the silages. Although these observations need confirmation, they may partly account for the differing milk yield response to dietary CT in the Hymes-Fecht et al. (2013) trial compared with trial 2. Elucidation of factors influencing CT-protein interactions in conserved BFT will provide insight into forage production and feeding practices that will maximize the utilization of existing CT-containing forages and other forages including alfalfa that are being engineered to express CT (Li et al., 2016).

\section{CONCLUSIONS}

Silages made over 2 yr from several harvests of alfalfa and BFT populations containing approximately 0.5, 1.0 , or $1.6 \%$ CT (DM basis) were fed as TMR in 2 trials to lactating dairy cattle. Compared with AS diets, diets containing BFT reduced MUN and urinary excretion of urea and total $\mathrm{N}$, which would be expected to reduce ammonia emissions from manure; however, little improvement was made in conversion of feed $\mathrm{CP}$ into milk true protein. Although earlier work suggested that milk and component yields were optimal at 1.0 to $1.6 \% \mathrm{CT}$, feeding BFT silage containing $0.5 \% \mathrm{CT}$ gave rise to the greatest yields of milk, ECM, milk protein, and other components in the current trials. Thus, further work is needed to identify the optimum CT concentration in forages for greatest milk production and protein-use efficiency of dairy cattle.

\section{ACKNOWLEDGMENTS}

The authors thank Nancy Ehlke for producing the BFT seed; Lee Massingill, Daniel Wendt, Richard Walgenbach, and the US Dairy Forage Research Center farm crew for establishing and ensiling the forages fed in this study; Jill Davidson and the US Dairy Forage Research Center barn crew for animal care and feeding and assisting with sampling; Wendy Radloff, Mary Becker, and Christy Davidson (US Dairy Forage Research Center) for assisting with laboratory analyses; and Peter Crump (University of Wisconsin-Madison) for assisting with statistical analyses.

\section{REFERENCES}

Albrecht, K. A., and R. E. Muck. 1991. Proteolysis in ensiled forage legumes that vary in tannin concentration. Crop Sci. 31:464-469.

AOAC. 1980. Official Methods of Analysis. 13th ed. Assoc. Off. Anal. Chem., Washington, DC.

AOAC. 1990. Official Methods of Analysis. 15th ed. Assoc. Off. Anal. Chem., Arlington, VA.

AOAC International. 1997. Official Methods of Analysis. 16th ed. AOAC Int., Washington, DC

Auldist, M. J., L. C. Marett, J. S. Greenwood, M. M. Wright, M. Hannah, J. L. Jacobs, and W. J. Wales. 2014. Replacing wheat with canola meal in a partial mixed ration increases the milk production of cows grazing at a restricted pasture allowance in spring. Anim. Prod. Sci. 54:869-878.

Broderick, G. A. 1987. Determination of protein degradation rates using a rumen in vitro system containing inhibitors of microbial nitrogen metabolism. Br. J. Nutr. 58:463-475.

Broderick, G. A., and K. A. Albrecht. 1997. Ruminal in vitro degradation of protein in tannin-free and tannin-containing forage legume species. Crop Sci. 37:1884-1891.

Broderick, G. A., and M. K. Clayton. 1997. A statistical evaluation of animal and nutritional factors influencing concentrations of milk urea nitrogen. J. Dairy Sci. 80:2964-2971.

Broderick, G. A., P. Uden, M. L. Murphy, and A. Lapins. 2004. Sources of variation in rates of in vitro ruminal protein degradation. J. Dairy Sci. 87:1345-1359.

Brun-Lafleur, L., L. Delaby, F. Husson, and P. Faverdin. 2010. Predicting energy $\mathrm{x}$ protein interaction on milk yield and milk composition in dairy cows. J. Dairy Sci. 93:4128-4143.

Buxton, D. R., and S. L. Fales. 1994. Plant environment and quality. Pages 155-199 in Forage Quality, Evaluation, and Utilization. G. C. Fahey Jr., M. Collins, D. R. Mertens, and L. E. Moser, ed. American Society of Agronomy, Madison, WI.

Cassida, K. A., T. S. Griffin, J. Rodriguez, S. C. Patching, O. B. Hesterman, and S. R. Rust. 2000. Protein degradability and forage quality in maturing alfalfa, red clover, and birdsfoot trefoil. Crop Sci. 40:209-215.

Chiquette, J., K. J. Cheng, L. M. Rode, and I. P. Milligan. 1989. Effect of tannin content in two isosynthetic strains of birdsfoot-trefoil (Lotus corniculatus L.) on feed digestibility and rumen fluid composition in sheep. Can. J. Anim. Sci. 69:1031-1039.

Coblentz, W. K., and J. H. Grabber. 2013. In situ protein degradation of alfalfa and birdsfoot trefoil hays and silages as influenced by condensed tannin concentration. J. Dairy Sci. 96:3120-3137.

Cochran, R. C., D. C. Adams, J. D. Wallace, and M. L. Galyean. 1986. Predicting digestibility of different diet with internal markers: Evaluation of four potential markers. J. Anim. Sci. 63:1476-1487.

Grabber, J. H. 2008. Mechanical maceration divergently shifts protein degradability in condensed-tannin vs. o-quinone containing conserved forages. Crop Sci. 48:804-812.

Grabber, J. H., and W. K. Coblentz. 2009. Polyphenol, conditioning, and conservation effects on protein fractions and degradability in forage legumes. Crop Sci. 49:1511-1522.

Grabber, J. H., W. K. Coblentz, H. Riday, T. C. Griggs, D. H. Min, J. W. MacAdam, and K. A. Cassida. 2015. Protein and dry-matter degradability of European- and Mediterranean-derived birdsfoot trefoil cultivars grown in the colder continental USA. Crop Sci. 55:1356-1364. 
Grabber, J. H., H. Riday, K. A. Cassida, T. C. Griggs, D. H. Min, and J. W. MacAdam. 2014. Yield, morphological characteristics, and chemical composition of European- and Mediterranean-derived birdsfoot trefoil cultivars grown in the colder continental United States. Crop Sci. 54:1893-1901.

Grabber, J. H., W. E. Zeller, and I. Mueller-Harvey. 2013. Acetone enhances the direct analysis of procyanidin- and prodelphinidinbased condensed tannins in lotus species by the butanol-HCl-iron assay. J. Agric. Food Chem. 61:2669-2678.

Hall, M. B. 2015. Determination of dietary starch in animal feeds and pet food by an enzymatic- colorimetric method: collaborative study. J. AOAC Int. 98:397-409.

Hintz, R. W., D. R. Mertens, and K. A. Albrecht. 1996. Effects of sodium sulfite on recovery and composition of detergent fiber and lignin. J. AOAC Int. 79:16-22.

Huhtanen, P., K. Kaustell, and S. Jaakkola. 1994. The use of internal markers to predict total digestibility and duodenal flow of nutrients in cattle given six different diets. Anim. Feed Sci. Technol. 48:211-227.

Hymes-Fecht, U. C., G. A. Broderick, R. E. Muck, and J. H. Grabber. 2013. Replacing alfalfa or red clover silage with birdsfoot trefoil silage in total mixed rations increases production of lactating dairy cows. J. Dairy Sci. 96:460-469.

Krause, K. M., and D. K. Combs. 2003. Effects of forage particle size, forage source, and grain fermentability on performance and ruminal pH in midlactation cows. J. Dairy Sci. 86:1382-1397.

Krueger, C. G., K. A. Albrecht, J. D. Reed, E. J. Bures, and V. N. Owens. 1999. Sodium sulfite effects on recovery and composition of detergent fibre and lignin from forage legumes varying in levels of proanthocyanidins. J. Sci. Food Agric. 79:1351-1356.

Li, P., Q. Dong, S. Ge, X. He, J. Verdier, D. Li, and J. Zhao. 2016 Metabolic engineering of proanthocyanidin production by repressing the isoflavone pathways and redirecting anthocyanidin precursor flux in legume. Plant Biotechnol. J. 14:1604-1618.

Lorenz, M. M., L. Alkhafadji, E. Stringano, S. Nilsson, I. MuellerHarvey, and P. Uden. 2014. Relationship between condensed tannin structures and their ability to precipitate feed proteins in the rumen. J. Sci. Food Agric. 94:963-968.

McDonald, P., A. R. Henderson, and S.J.E. Heron. 1991. The Biochemistry of Silage. Chalcombe Publications, Marlow, UK.

Miller, P. R., and N. J. Ehlke. 1996. Condensed tannins in birdsfoot trefoil: Genetic relationships with forage yield and quality in NC83 germplasm. Euphytica 92:383-391.

Min, B. R., T. N. Barry, G. T. Attwood, and W. C. McNabb. 2003. The effect of condensed tannins on the nutrition and health of ruminants fed fresh temperate forages: A review. Anim. Feed Sci. Technol. 106:3-19.

Misselbrook, T. H., J. M. Powell, G. A. Broderick, and J. H. Grabber. 2005. Dietary manipulation in dairy cattle: Laboratory experiments to assess the influence on ammonia emissions. J. Dairy Sci. 88:1765-1777.

Muck, R. E. 1987. Dry matter level effects on alfalfa silage quality. 1. Nitrogen transformations. Trans. ASAE 30:7-14.

Muck, R. E., and J. T. Dickerson. 1988. Storage temperature effects on proteolysis in alfalfa silage. Trans. ASAE 31:1005-1009.

Mueller-Harvey, I. 2006. Review: Unravelling the conundrum of tannins in animal nutrition and health. J. Sci. Food Agric. 86:20102032 .
Nousiainen, J., K. J. Shingfield, and P. Huhtanen. 2004. Evaluation of milk urea nitrogen as a diagnostic of protein feeding. J. Dairy Sci. 87:386-398.

NRC. 2001. Nutrient Requirements of Dairy Cattle. 7th rev. ed. Natl. Acad. Sci., Washington, DC.

Pahlow, G., R. E. Muck, F. Driehuis, S. J. W. H. Oude Elferink, and S. F. Spoelstra. 2003. Microbiology of ensiling. Pages 31-93 in Silage Science and Technology. Agron. Monogr. 42. D. R. Buxton, R. E. Muck, and J. H. Harrison, ed. Am. Soc. of Agronomy (ASA), Crop Sci. Soc. of America (CSSA), and Soil Sci. Soc. of America (SSSA), Madison, WI.

Patra, A. K., and J. Saxena. 2011. Exploitation of dietary tannins to improve rumen metabolism and ruminant nutrition. J. Sci. Food Agric. 91:24-37.

Petit, H. V., A. R. Pesant, G. M. Barnett, W. N. Mason, and J. L. Dionne. 1992. Quality and morphological characteristics of alfalfa as affected by temperature, soil moisture, $\mathrm{pH}$ and phosphorus fertilization. Can. J. Plant Sci. 72:147-162.

SAS Institute Inc. 2013. 9.4-Guide to Software Updates. SAS Inst. Inc., Cary, NC.

Valadares, R. F. D., G. A. Broderick, S. C. Valadares, and M. K. Clayton. 1999. Effect of replacing alfalfa silage with high moisture corn on ruminal protein synthesis estimated from excretion of total purine derivatives. J. Dairy Sci. 82:2686-2696.

Van Soest, P. J. 1994. Nutritional Ecology of the Ruminant. 2nd ed. O \& B Books Inc., Corvallis, OR.

Van Soest, P. J., J. B. Robertson, and B. A. Lewis. 1991. Methods for dietary fiber, neutral detergent fiber and non starch polysaccharides in relation to animal nutrition. J. Dairy Sci. 74:3583-3597.

Waghorn, G. C. 2008. Beneficial and detrimental effects of dietary condensed tannins for sustainable sheep and goat productionProgress and challenges. Anim. Feed Sci. Technol. 147:116-139.

Waghorn, G. C., and I. D. Shelton. 1997. Effect of condensed tannins in Lotus corniculatus on the nutritive value of pasture for sheep. J. Agric. Sci. (Camb.) 128:365-372.

Waghorn, G. C., M. J. Ulyatt, A. John, and M. T. Fisher. 1987. The effect of condensed tannins on the site of digestion of amino acids and other nutrients in sheep fed on Lotus corniculatus L. Br. J. Nutr. 57:115-126.

Wang, Y., G. B. Douglas, G. C. Waghorn, T. N. Barry, and A. G. Foote. 1996a. Effect of condensed tannins in Lotus corniculatus upon lactation performance in ewes. J. Agric. Sci. (Camb.) 126:353-362.

Wang, Y., G. C. Waghorn, W. C. McNabb, T. N. Barry, M. J. Hedley, and I. D. Shelton. 1996b. Effect of condensed tannins in Lotus corniculatus upon the digestion of methionine and cysteine in the small intestine of sheep. J. Agric. Sci. 127:413-421.

Woodward, S. L., M. J. Auldist, P. J. Laboyrie, and E. B. L. Jansen. 1999. Effect of Lotus corniculatus and condensed tannins on milk yield and milk composition of dairy cows. Proc. N.Z. Soc. Anim. Prod. 59:152-155.

Woodward, S. L., P. J. Laboyrie, and E. B. L. Jansen. 2000. Lotus corniculatus and condensed tannins-Effects on milk production by dairy cows. Asian-australas. J. Anim. Sci. 13:521-552. 